\title{
The effects of different planting methods on sweet potato
}

\author{
Adrienn Szarvas - Margit Szél Hódi - Tamás Monostori \\ University of Szeged Faculty of Agriculture, Hódmezővásárhely \\ szarvasadrienn@mgk.u-szeged.hu
}

\section{SUMMARY}

\begin{abstract}
The aim of our research program is to develop the production technology and to examine the possibilities of the utilization of sweet potato (Ipomea batatas (L.) Lam.). In 2016 and 2017, production technology experiments were set up with four replications in a randomized block design on an alluvial soil in Deszk, Hungary. In our field experiments, we obtained results of planting material production, planting methods and the optimized fertilization of sweet potato. Experimental plots were set up either with or without ridges. In heavy soils - where usually ridge planting is preferred -, in 2016, the production technology without ridges proved to be more effective. In 2017, however, we got opposite results: based on the result of the harvest, the production technology with ridges proved to be more effective. The transplants originating from cuttings from tubers (primary transplants) or from shoots (secondary transplants) did not show significant differences, however, in both years, yield levels were higher on ridges with secondary transplants.

Sweet potato yield may vary widely among producers due to improper ridging and planting orientation. The aim of this study was to establish the proper ridging and planting orientation, so as to enhance constant reliable yields among sweet potato producing farmers.
\end{abstract}

Keywords: Ipomoea batatas, sweet potato, primary and secondary transplants, production technology

\section{INTRODUCTION}

Sweet potato (Ipomoea batatas (L.) Lam) is a perennial food crop of the morning glory family, (Convolvulaceae) and widely cultivated as an annual crop in tropical and warmer temperate climates (Sihachakr et al. 1995, Huaman 2002, Demissew 2006). It is one of the main food crops in Africa and other tropical regions, but it can be found anywhere in the world, where the climate is suitable for them (Net1). Sweet potato is grown in a wide range of environments, from the humid tropics to mild temperate zones (Sullivan et al. 1997). The storage roots of sweet potato are used as staple food, raw material for alcohol production and animal feed in many countries. China accounts for about $85 \%$ of the world's production where roots are used as food (like roasted, baked forms), for direct consumption, animal fodder and as raw material for starch and noodle manufacture (Theberge 1985, Woolfe 1992, Martin 1994, Ikeorgu 2000). Sweet potato is a crop with a great potential in decreasing hunger in the tropical world. As a life-saver, the Japanese used it when typhoons demolished their rice fields, just as much as it kept millions of people from starvation in China in 1960s (CIP 1998). The intensity of the sweet potato's orange flesh colour is directly correlated to its betacarotene content. Human bodies can typically produce vitamin A from the beta-carotene in orange-fleshed sweet potato. Contents of minerals and vitamins such as $\mathrm{A}, \mathrm{B}_{2}, \mathrm{C}$, and $\mathrm{E}$ are high in leaves in comparison with other vegetables. For this reason, both roots and foliage are used as a protein and vitamin source (Chen et al. 1977, Mora et al. 1992, Wethli and Paris 1995 , Ali et al. 1999).

Sweet potato is easy to cultivate with little fertilizer input and produces a high volume of roots per hectare, matures fast, has good keeping qualities and is affected by few pests and diseases. Sweet potato is one of the important sources of calories for people in the developing countries and is the seventh most important food crop grown in more than one hundred countries. It is an important staple food for large sectors of the world population in the tropics where both the roots and tender shoots are eaten as a vital source of nutrients (Woolfe 1992, Collins 1995).

Sweet potato can be cultivated in a wide range of soil, prefers sandy-loam soil, doing poorly on clay soil. Sweet potatoes are fairly tolerant to a wide range of soil $\mathrm{pH}$ but will grow best in soils with a $\mathrm{pH}$ of 5.5 to 6.5. Comparison of ridge and flat cultivation, sweet potato is usually planted on ridges technology (Brandenberger 2014). It is important to determine whether among the local conditions planting on ridges or without ridges results improve higher yields of storage roots.

Many producers believe that high yields are produced from very high ridges, yet Dhliwayo and Chiunzi (2004) reiterate that small to medium sized ridges that are easy to make may produce good yields as long as fertility is present. Ridges should also be high enough to prevent water logging (Gomes 1999). Variable planting methods are being used by sweet potato producers in the world.

Sweet potato tubers and foliage are being sold in China as animal fodder (Woolfe 1992). In the future it can increase the incomes of farmers and producers. Intercrops with sweet potatoes represent also a valuable production alternative for mixed animal and crop farm system where the animal component depends on farm crops. Several research results shows promising perspectives both for meat and milk production (Baker 1978).

In Hungary, sweet potato is cultivated for thirty years (Horváth 1991ab), but it became well-known in the last years only. It has recently become so popular here that the farmers cannot produce enough sweet potatoes to fill up the Hungarian market from 
domestic harvest. In spite of the published cultivation technology sheets and experiences, yield security is still not fully solved, growing site- and genotypespecific advices are still missing.

In Hungary, the storage root yields range between 18 and $25 \mathrm{ha}^{-1}$, depending on the production site and the applied technology (Net2). Sweet potato grows best where average temperatures are $20{ }^{\circ} \mathrm{C}$. The crop can be damaged by frost, and this fact restricts the cultivation of sweet potato in the temperate regions to areas with a minimum frost-free period of 5 months (Berényi and Szabó 2001).

Our main objectives were to study the possibilities for increasing the sweet potato yield potential, stability and efficiency of production.

In this work we evaluate the yield of sweet potato with different fertilizer treatments and comparison of the effect of planting primary or secondary cuttings in 2016 and 2017.

\section{MATERIALS AND METHODS}

The experiment was conducted in Deszk, Hungary on a clay loam soil $\left(\mathrm{K}_{\mathrm{A}} 46\right)$ of medium to very good nutrient content. There were a total of three treatments including the untreated control. Ridges were formed on one half of our experimental area, on the other half rows were formed without ridges. The experimental setup was Randomized Complete Block Design (RCBD) in four replicates. The plot size was $6 \mathrm{~m} \times 2 \mathrm{~m}$ including 40 transplants in two rows. The seedlings derived from the Bivalyos Tanya Family Farm. For the experiments, we used the Ásotthalmi-12 orangefleshed sweet potato variety.

The cuttings were planted on $31^{\text {st }}$ May 2016 and $9^{\text {th }}$ of June 2017 on ridges and flat, without ridges, with spacing of $100 \mathrm{~cm} \times 30 \mathrm{~cm}$. The experimental area was $300 \mathrm{~m}^{2}$, altogether including 960 pieces of cuttings. The cuttings were planted with two thirds of the slip below the soil surface for proper establishment.

The fertilizer treatments were applied at four weeks after planting in both years, 2016 and 2017. Throughout the experiment, there was regular weeding applied. The weeds were effectively controlled manually. No serious insect pest or disease problems occurred during the growing season. The treatments were designated as follows: K-control, 1-first fertilizer treatment, 2-second fertilizer treatment. The fertilizers used were NPK, in the forms of calcium ammonium nitrate $(27 \% \mathrm{~N})$, superphosphate $\left(20 \% \mathrm{P}_{2} \mathrm{O}_{5}\right)$ and potassium sulphate $\left(51 \% \mathrm{~K}_{2} \mathrm{O}\right)$. The fertilizer rates (in active ingredient) were as follows:

$1^{\text {st }}$ treatment: nitrogen $45 \mathrm{~kg} \mathrm{ha}^{-1}$, phosphorus $90 \mathrm{~kg}$ $\mathrm{ha}^{-1}$, potassium $135 \mathrm{~kg} \mathrm{ha}^{-1}$,

$2^{\text {nd }}$ treatment: nitrogen $67.5 \mathrm{~kg} \mathrm{ha}^{-1}$, phosphorus $90 \mathrm{~kg}$ $\mathrm{ha}^{-1}$, potassium $180 \mathrm{~kg} \mathrm{ha}^{-1}$.

The experiments with the planting material started at the end of April in both years. Ten plastic trays filled with peat were used where the sprouting of sweet potato storage roots had already been started.
The primary cuttings were cut directly from the storage roots, the lower leaves removed, and the slips were planted into the experimental trays.

Secondary cuttings were derived from the sprouting of the primary ones. Both primary and secondary cuttings were used in our field experiments to get information that the primary or the secondary cuttings will give us more yield.

In 2017, the sweet potato foliage was cut and measured by experimental plots. It was intended to know if there is any closer relationship between the effects of the treatments applied in sweet potato tubers and foliage weight.

\section{Statistical analysis}

Data were subjected to analysis of variance (ANOVA) using. Significant differences between treatment means were separated using least significant difference $\left(\mathrm{LSD}_{5 \%}\right)$. Test at $5 \%$ level of significance (Harnos és Ladányi 2005).

\section{RESULTS AND DISCUSSION}

The experimental plots were harvested on $15^{\text {th }}$ October 2016 and 2017. The harvesting was done when the leaves had nearly turned brown.

Relationship between the sweet potato yields, fertilizer treatments and foliage weight in $\mathbf{2 0 1 7}$

Before harvest in 2017, the foliage was cut and measured. It was evident from the results that the use of the $2^{\text {nd }}$ fertilizer treatment increased both the sweet potato foliage weight and the yield of tubers. Neither with or without ridges technology, the $2^{\text {nd }}$ fertilizer treatments had a significant effect on sweet potato yield and foliage weight, so the $2^{\text {nd }}$ fertilizer treatment decreased both. Extrapolating the foliage weight to one hectare, Figure 1 shows that the foliage weight produced approximately 10 tons $\left(9.63 \mathrm{t} \mathrm{ha}^{-1}\right.$ in ridges technology and $9.89 \mathrm{t} \mathrm{ha}^{-1}$ in flat (without ridges) technology with the second fertilizer treatment).

Figure 1: Sweet potato foliage weight in 2017

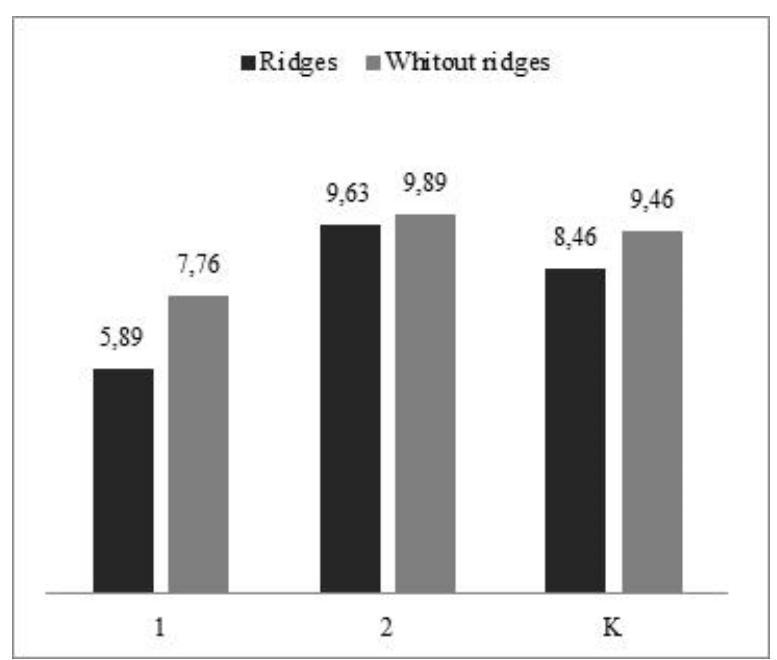

Note: unit of measure is tons per hectare. 
Average yield of sweet potato plants in ridge and flat (without ridge) planting in 2016 and 2017

In 2016, the total sweet potato yield harvested on the experimental plots with ridges was $433 \mathrm{~kg}$ while from the plots without ridges we harvested a total of $537 \mathrm{~kg}$. Regarding the total number of plants being 960 , it means $1.01 \mathrm{~kg}$ sweet potato yield per plant that is a good result according to bibliographical data. This was an unexpected result because on heavier soils the ridge planting is recommended worldwide.

In 2017, the total sweet potato yield harvested on the experimental plots with ridges was $296 \mathrm{~kg}$ while from the plots without ridges we harvested a total of $248 \mathrm{~kg}$. Regarding the total number of plants being 960 , it means $0.5 \mathrm{~kg}$ sweet potato yield per plant that is not a good result compared to the last year. We could recognize that in 2017 the total yield of sweet potato was half amount as in the last year. The main reasons of this opposite result could be the weather and the monoculture problems.

Extrapolating yield amounts to hectare, Figure 2 shows that in 2016, the sweet potato yield per hectare was higher in the flat plots $\left(35.99-38.32 \mathrm{t} \mathrm{ha}^{-1}\right)$ compared to the plots with ridges (28.99-30.33 $\left.\mathrm{tha}^{-1}\right)$. We could see significant differences between the first fertilizer treatment $\left(\mathrm{LSD}_{5 \%}=4.59\right)$ and the control $\left(\mathrm{LSD}_{5 \%}=4.097\right)$.

Figure 2: Sweet potato yield in 2016

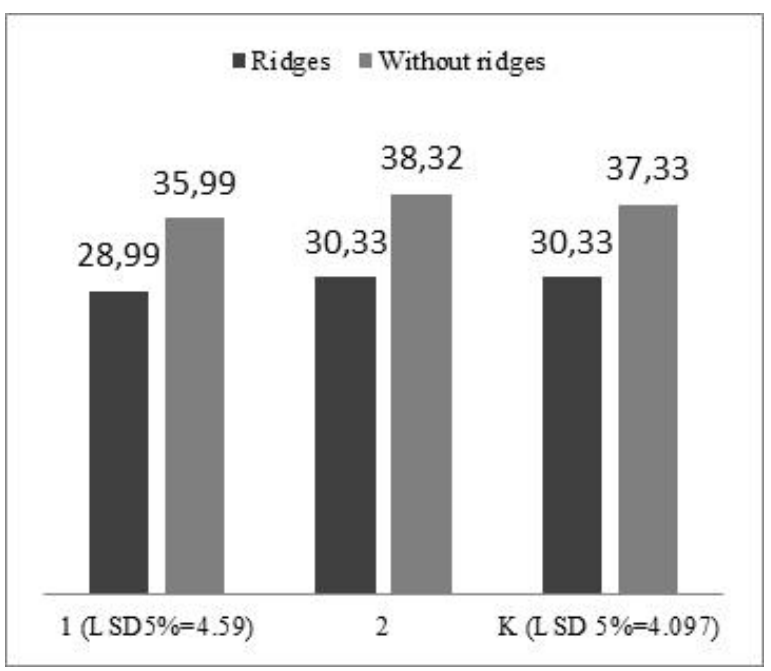

Note: unit of measure is tons per hectare

In 2017, we got opposite results because the ridges technology gave higher yields. Figure 3 shows that sweet potato yield per hectare was higher in the plots with ridges (18.29-22.06 $\left.\mathrm{tha}^{-1}\right)$ compared to the flat plots $\left(16.48-18.26 \mathrm{tha}^{-1}\right)$. The result shows significant differences on the control group $\left(\mathrm{LSD}_{5 \%}=4.18\right)$. When we compare the results of the years of treatments, both with ridges and without ridges technology, there was a significant differences between the data of the two years.
Figure 3: Sweet potato yield in $\mathbf{2 0 1 7}$

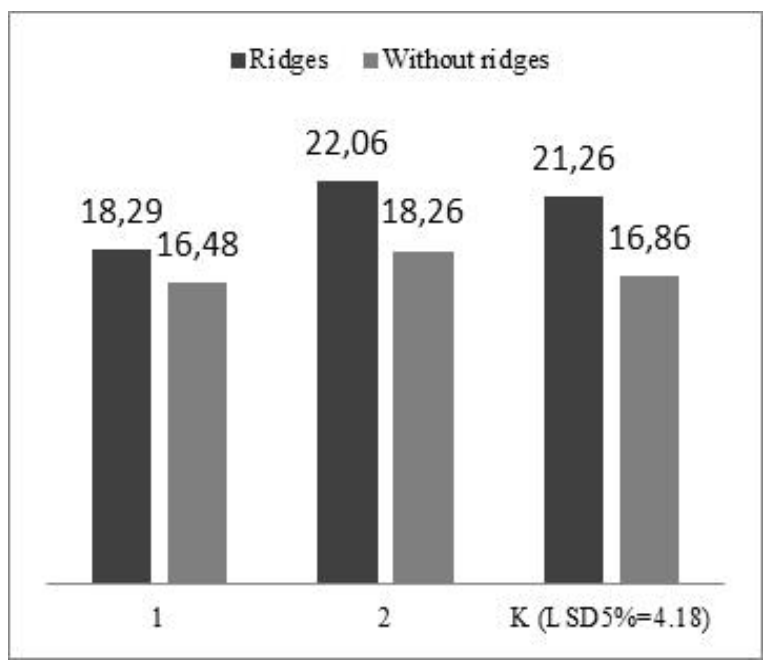

Note: unit of measure is tons per hectare

Effects of slip origin on sweet potato yield in ridge planting in 2016 and 2017

The first five plants from each row were harvested and weighed separately. These plants had grown from cuttings from tubers (primary transplants) or from shoots (secondary transplants).

Figure 4 shows that in 2016 and 2017 on ridges planting the secondary cuttings gave the best results. Extrapolating the yields to one hectare, the control treatments produced the highest yield followed by the second fertilizer treatment, and the first fertilizer treatments gave the poorest results in both years. In 2016 with ridges technology, the difference between the yields of plants originating from primary and secondary cuttings $\left(29.83\right.$ vs. $\left.38.04 \mathrm{t} \mathrm{ha}^{-1}\right)$ could be even 9 tons. In 2017 with ridges technology the difference between the yields of plants originating from primary and secondary cuttings (19.39 vs. 27.59 $\mathrm{t} \mathrm{ha}^{-1}$ ) could be even 8 tons.

Figure 4 shows that on ridges technology between 2016 and 2017, with primary and secondary cuttings indicated significant differences.

\section{CONCLUSIONS}

It is evident from this work that we got novel results about the utility of cuttings of different origin, as well as about the effects of planting method and various fertilizer doses on storage root yield. All over the world, especially on clay soils, sweet potato growing on ridges or beds is common. This offers well-aerated and well-drained conditions for storage root development, furthermore facilitates harvesting (Lebot 2009).

In 2016, sweet potatoes in flat planting gave higher yield that was an unexpected result. In 2017, we got opposite results; the ridge planting increased the sweet potatoes yield. The appropriate choice of planting material (primary transplants or secondary transplants) can result even an extra sweet potato yield, but further examinations are needed in the future. 
Figure 4: Yield of primary and secondary transplants in ridge planting in 2016 and 2017

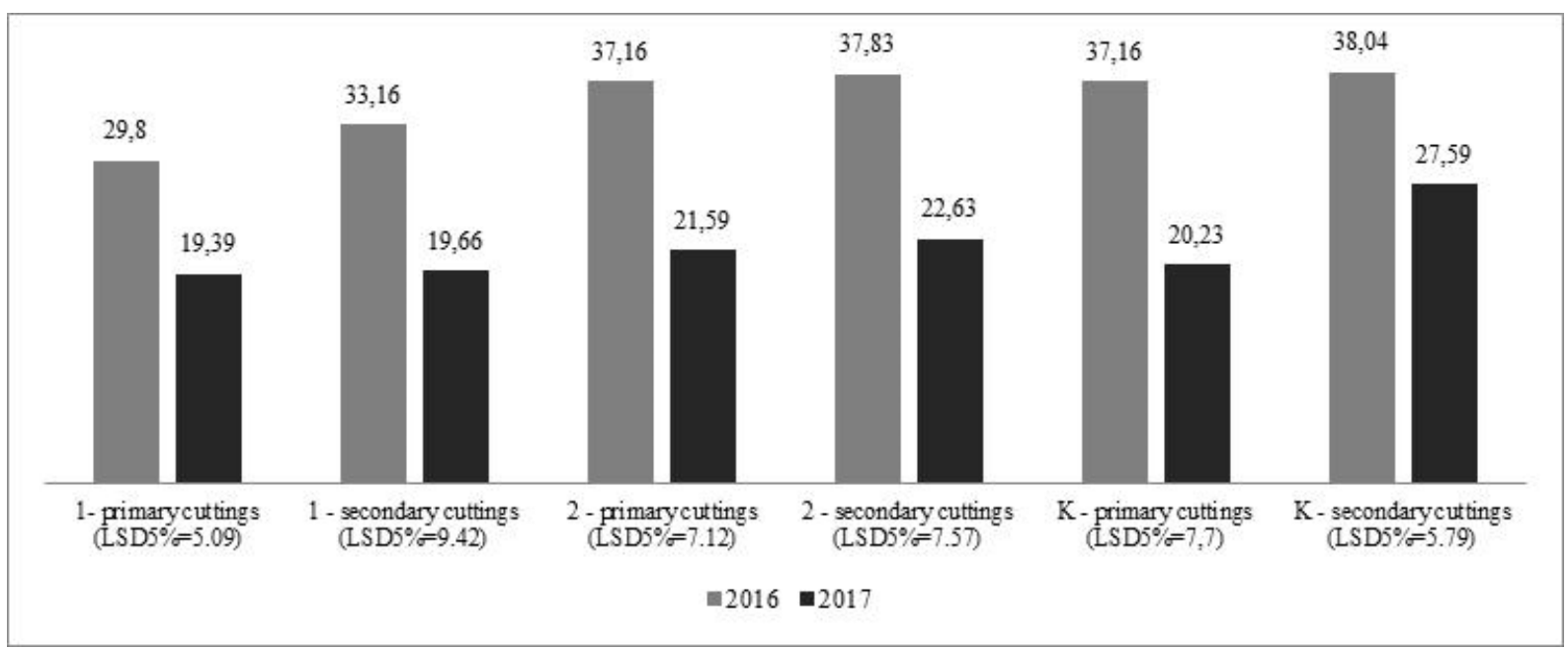

Note: unit of measure is tons per hectare

Basic reference materials are needed to provide scientist with authoritative, up to date information on compositional, nutritional, quality, consumption, soil fertilization, different cultivation aspects of the sweet potato. Although it is hoped that this experiment will be of particular value to those in other researchers or producers with the most pressing cultivation problems of sweet potato.

\section{ACKNOWLEDGEMENTS}

I offer my sincere thanks to the Bivalyos Tanya Family Farm and to my family.

\section{REFERENCES}

Ali, M. A.-Tageldin, T. H.-Solaiman. E. M. (1999): Effect of sweet potato tops or roots in growing rabbit diets on growth performance, digestibility, carcass traits and economic efficiency. Egyptian J. Rabbit Sci. 9: 13-23.

Baker, J. (1978): Sistema de cultivo camote-frijol de gufa origna. San Andés, EL. Salvader. CENTA. 2.

Berényi B.-Szabó L. (2001): Növénytermesztés trópusokonszubtrópusokon. Mezőgazdaság Szaktudás Kiadó. Budapest. 72.

Brandenberger, L.-Shrefler, J.-Rebek, E.-Damicone, J. (2014) Sweet potato production. [In: Sullivan O', J. N. et al. (1997): Nutrient disorders of sweetpotato. ACIAR Monograph.] 48: 136.

Chen, M. C.-Yi, J. J.-Hsu, T. C. (1977): The nutritive value of sweet potato vines produced in Taiwan for cattle. -3 . Feeding value for milk. -4 . Feeding value for growth of different forms. J. Agricultural. Assoc. China. 99: 39-45.

CIP (1998): International Potato Center (CIP) Annual Report. Lima. Peru. 68.

Collins, W. W. (1993): Root vegetables: New uses for old crops [In: Janick, J.-Simon, J. E. (eds.) New Crops.] Wiley. New York. USA. 535-537.

Demissew, S. (2006): Convolvulaceae. [In: (Hedberge, I. et al. (eds.) Flora of Ethiopia. Gentianaceae to Cyclocheilaceae.] Addis Ababa - Uppsala. Ethiopia - Sweden. The National Herbarium. 5: 161-231.

Dhliwayo, P.-Chiunzi, P. D. (2004). A Guide to profitable sweet potato production, Harare. Biotechnology Trust of Zimbabwe. 3-9.
Gomes, G. (1999): Sweet potato Growth Characteristics. First Edition. Academic Press. New York. USA. 4-7.

Harnos Zs.-Ladányi M. (2005): Biometria agrártudományi alkalmazásokkal. Aula Kiadó Kft. Budapesti Corvinus Egyetem. 330.

Horváth L. (1991a): A batáta Magyarországon: Védelem, tárolás. Kertészet és Szőlészet. 40. 16: 16.

Horváth L. (1991b): A batáta szaporítása. Kertészet és Szőlészet. 40. $21: 7$.

Net1: http://www.greenfo.hu/hirek/2014/07/01/batatafalvi-batatabaratai

Net2: $\quad$ http://magyarmezogazdasag.hu/2016/01/06/hazankbantermesztheto-batata

Huaman, Z. (2002): Systematic botany and morphology of sweet potato plant. Sweet potato germplasm management (Ipomoea batatas). CIP Training manual section.

Ikeorgu, J. E. G. (2000): Root and Tuber Crops of Nigeria. Production, Challenges and Future. J. Agronomy in Nigeria. University of Ibadan. Nigeria. 67-69.

Lebot, V. (2009): Tropical root and tuber crops: cassava, sweet potato, yams and aroids. Crop production science in horticulture (17). CAB books. CABI. Wallingford. UK.

Martin, C. (1994): Welcome address to participants, Sweet potato situation and priority research in West and Central Africa. Proceedings of the workshop held in Douala, Cameroon. 27-29 July 1992. International Potato Center (CIP). Lima. Peru. 142.

Mora, L.-Dominguez, P. L.-Calderon, R.-Quintano, J. (1992): Notes on the use of sweet potato (Ipomoea batatas) foliage in diets for weaned pigs. Zootechnia de Cuba. 2: 85-90. 
Sihachakr, D. R.-Haïcour, J. M.-Cavalcante-Alves, S.-Tizroutine, M.-Allot, I.-Mussio, A.-Servaes, D.-Nozhgé, G. (1995) Ducreux Embryogenèse somatique chez la patate douce (Ipomoea batatas (L.) Lam.): Caractérisation et régénération des plantes. [In: J. Dubois, Y.-Demarly-Aupelf-Uref (eds.) Quel avenir pour l'amélioration des plantes.] John Libbey. EUROTEXT. 251-261.
Theberge, R. L. (1985): Common African pests and diseases of cassava, yam, sweet potato and cocoyams. International Institute of Tropical Agriculture (IITA). Ibadan. Balding+Mansell Ltd. England. 212.

Wethli, E.-Paris, C. (1995): The use of raw materials cultivated in Mozambique in the feeding of growing chickens. Liv. Res. Rural Dev. 7: 54-59.

Woolfe, J. A. (1992): Sweet potato: An Untapped Food Resource. Cambridge University Press. Cambridge. UK. 409-472. 